\title{
Anatomical Measurement of Normal Eustachian Tube on the Temporal Bone Computed Tomography Imaging
}

\author{
Yanti Anita Ratag ${ }^{1}$, Sri Asriyani ${ }^{1}$, Bachtiar Murtala ${ }^{1}$, Masyita Gaffar $^{2}$
}

\begin{abstract}
Abstrak
Tujuan: Menggambarkan pengukuran anatomis tuba Eustachius normal pada pencitraan Computed Tomography (CT) tulang temporal. Metode: Ini adalah penelitian deskriptif tuba Eustachius normal dengan mengukur diameter pretimpani, sudut tubotimpani dan panjang pars kartilago tuba Eustachius normal menggunakan teknik rekonstruksi multiplanar pada pencitraan CT tulang temporal dari 58 sampel di beberapa rumah sakit di Makassar. Semua sampel dibagi lagi menjadi kelompok laki-laki dan perempuan, serta kelompok sisi kanan dan kiri. Kami juga membagi sampel menjadi 6 kelompok usia. Hasil: Rerata diameter pretimpani pada kelompok pria adalah 4,62 mm dan pada kelompok wanita adalah 4,36 mm. Rerata diameter pretimpani adalah 4,59 mm pada kelompok sisi kanan dan 4,36 mm pada kelompok sisi kiri. Rerata sudut tubotimpani adalah 143,5o pada kelompok pria dan 143,30 pada kelompok wanita. Nilai rerata sudut tubotimpani tidak memiliki perbedaan di kedua sisi telinga. Rerata panjang pars kartilago tidak memiliki perbedaan antara kelompok pria dan wanita dan juga antara sisi kanan dan kiri. Simpulan: Diameter pretimpani lebih besar pada kelompok pria dan kelompok sisi kanan. Sudut tubotimpani dan panjang kartilago tuba Eustachius tidak memiliki perbedaan yang signifikan pada semua kelompok.
\end{abstract}

Kata kunci: tuba eustachius, diameter pretimpani, sudut tubotimpani, panjang kartilago, CT tulang temporal

\begin{abstract}
Objectives: To described the anatomical measurement of normal Eustachian tube on the temporal bone Computed Tomography (CT) imaging. Methods: This was a descriptive study of a normal Eustachian tube that measured the pretympanic diameter, tubotympanic angle and cartilage length of normal Eustachian tube using multiplanar reconstruction technique on temporal bone CT imaging of 58 consecutive samples at several hospitals in Makassar. All samples were subdivided into male and female groups and also into the right side and left side groups. We also subdivided the samples into 6 groups of age. Results: The mean of pretympanic diameter was 4,62 $\mathrm{mm}$ in the male's group and 4,36 $\mathrm{mm}$ in the female's group. The mean of pretympanic diameter was 4,59 $\mathrm{mm}$ in the right side group and 4,36 $\mathrm{mm}$ in the left side group. The mean of tubotympanic angle was 143,50 in the male's group and 143,30 in the female's group. The mean of tubotympanic angle had no difference in both sides of the ear. The mean of cartilage length had no difference between male's and female's group and also between the right side and left side group. Conclusion: Pretympanic diameter was greater in the male's group and right side group. Tubotympanic angle and cartilage length of Eustachian tube had no significant difference in all groups.
\end{abstract}

Keywords: Eustachian tube, pretympanic diameter, tubotympanic angle, cartilage length, temporal bone CT

Affiliasi penulis: ${ }^{1}$ Department of Radiology, Faculty of Medicine, Hasanuddin University, Makassar, Indonesia. ${ }^{2}$ Department of ENT, Faculty of Medicine, Hasanuddin University, Makassar, Indonesia. Korespondensi: Instalasi Radiologi Rumah Sakit Pendidikan Universitas Hasanuddin, JI.Perintis Kemerdekaan KM 11, Kecamatan Tamalanrea, Makassar 90245 [dryanti.anita@gmail.com] Telp: 081340157276

\section{INTRODUCTION}

Knowledge of the structure and function of the Eustachian tube system is necessary to understand the pathogenesis of middle-ear diseases. ${ }^{1}$ The Eustachian tube is very important in pathogenesis and management prognosis because Eustachian tube dysfunction is an important cause of middle ear 
disease. $^{2}$ The main function of the Eustachian tube is ventilation and drainage of the middle ear. Variation in its anatomical position is believed to be a predisposing factor for Eustachian tube dysfunction. ${ }^{3}$

The Eustachian tube is part of a system of contiguous organs, including the nose, pharynx, palate, middle ear, and mastoid air cells. ${ }^{4}$ The Eustachian tube consists of three parts, namely the osseous portion, the cartilage portion, and the junctional portion. The junctional portion is located between the two parts mentioned earlier. ${ }^{3,5}$ The cartilaginous portion is proximal and opens into the nasopharynx, and the osseous portion is distal and opens into the anterior middle ear. The junctional portion is a part of the tube at which the cartilage and osseous portions connect, which was previously thought to be the narrowest part of the tubal lumen called the isthmus. ${ }^{5,6}$

The Eustachian tube usually opens three or four times per minute. It is opened by swallowing to allow the distribution of pressure between the middle ear and pharynx. Impaired patency of the tube causes a relative negative pressure in the middle ear. ${ }^{3}$ Dysfunction of the Eustachian tube system has a direct role in the pathogenesis and management of the middle-ear disease. ${ }^{6}$

Radiological evaluation using computed tomography (CT) modalities is important when evaluating the middle ear and mastoid. ${ }^{7}$ The multiplanar reconstruction technique has made it possible to obtain images that are parallel or perpendicular to the long axis of the Eustachian tube so that it is useful to better understand the anatomy and diseases associated with the Eustachian tube. Measurement of the multidimensional parts of the Eustachian tube can provide a complete picture to understand the condition and function of the tube and to predict the prognosis of middle ear diseases. ${ }^{8,9}$

\section{METHODS}

This is a descriptive study of a normal Eustachian tube. We measured the pretympanic diameter, tubotympanic angle and cartilage portion length of normal Eustachian tube using the multiplanar reconstruction (MPR) technique on temporal bone CT imaging of 58 consecutive samples. All samples were patients who came to the hospital with complaints of middle ear discomfort in one ear who underwent temporal bone CT scan. This study is a part of a large study that measures the comparison of Eustachian tube in patients with safe and dangerous types of suppurative chronic otitis media, but what is sampled in this study is the normal ear side.

The research was conducted at Wahidin Sudirohusodo Hospital, Hasanuddin University Hospital and Jaury Academic Hospital in January 2018 to December 2019 period until the number of samples was fulfilled. Exclusion criteria in this study were tumors of the temporal bone, nasopharyngeal tumors, history of temporal bone trauma, history of temporal bone and neck surgery, congenital head and neck abnormalities (such as low set ears, micrognathia, cleft palate, craniosynostosis, etc.), hypertrophy or persistent adenoids, nasopharyngeal tumors and history of the previous mastoidectomy and tympanoplasty.

All samples were subdivided into male and female groups and also into the right side and left side groups. All samples in this study were aged ten years and over, which were further divided into six age groups. Group 1 was a sample of 11-20 years old, group 2 was 21-30 years old, group 3 was 31-40 years old, group 4 was 41-50 years old, group 5 was 51-60 years old, group 6 was over 60 years old. The age division of groups was intended to describe the distribution of samples taken in this study. The reason why the sample was chosen is ten years old and above is because the ear structure is considered mature as the ear structure in adults. ${ }^{10}$

The measurements compared in this study are the values obtained in the male and female groups, as well as the values obtained on the right side and left side. In addition to comparing the picture of the normal Eustachian tubes in these groups, this study also determined the mean value in the Eustachian tubes of each group to be a useful source of information in the diagnosis and treatment of diseases of the middle ear.

The Eustachian tube is a structure that cannot be seen in plain view. This is because of its deep position, so it can't be seen by otoscopic examination. Even during the intraoperative period, this structure can't be seen as a whole. However, the Eustachian tube can 
be easily evaluated using a CT imaging. The osseous portion of the Eustachian tube can be directly seen on axial or coronal slices. The full diameter of the cartilage portion of the tube can only be seen on the axial view. Most of the time, the cartilage portion of the Eustachian tube is in a closed state at the time of evaluation, so that this structure will only be seen in coronal slices and reformates. We can measure the length of the cartilage part using the multiplanar reconstruction technique. The anatomical measurement of the Eustachian tube in terms of diameter, length and angle can be assessed by regular protocol examination of temporal bone CT imaging.

There were 3 parameters measured in this study, namely pretympanic diameter, tubotympanic angle and length of the cartilage portion. The pretympanic diameter is the largest diameter of the pretympanic segment, which is the most lateral segment of the Eustachian tube, expressed in millimeters (Picture 1).

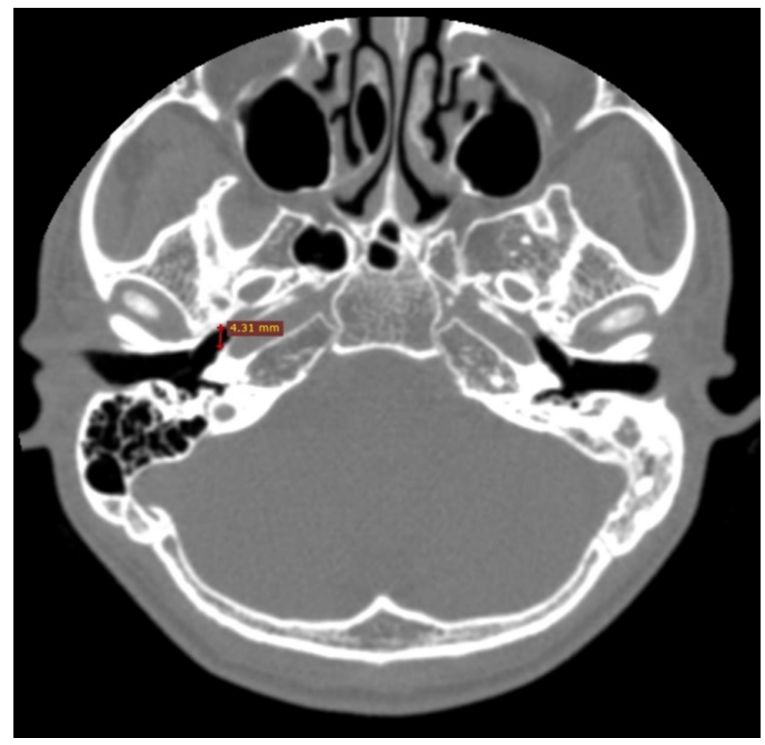

Figure 1. Right pretympanic diameter is measured on an axial view of temporal bone CT (marked with a red line).

The tubotympanic angle is the angle formed by the long axis through the external acoustic canal and the long axis through the Eustachian tube (Picture 2). Both pretympanic diameter and tubotympanic angle were measured on the axial view of temporal bone CT imaging. The length of the cartilage portion is the distance between the bony eminence at the caudamedial end of the Eustachian tube and the end of the tuberous torus measured on a coronal view of temporal bone CT imaging using multiplanar reconstruction technique, expressed in centimeters (picture 3). All CT images were obtained using 125 $\mathrm{mAs}$ and $120 \mathrm{kV}$ with multi-detector row CT scanners. Images were taken parallel to the orbitomeatal line and slide thickness varied slightly between $0.5 \mathrm{~mm}$ and 0.6 $\mathrm{mm}$. The window level was $600 \mathrm{HU}$ and the window width was $3200 \mathrm{HU}$.

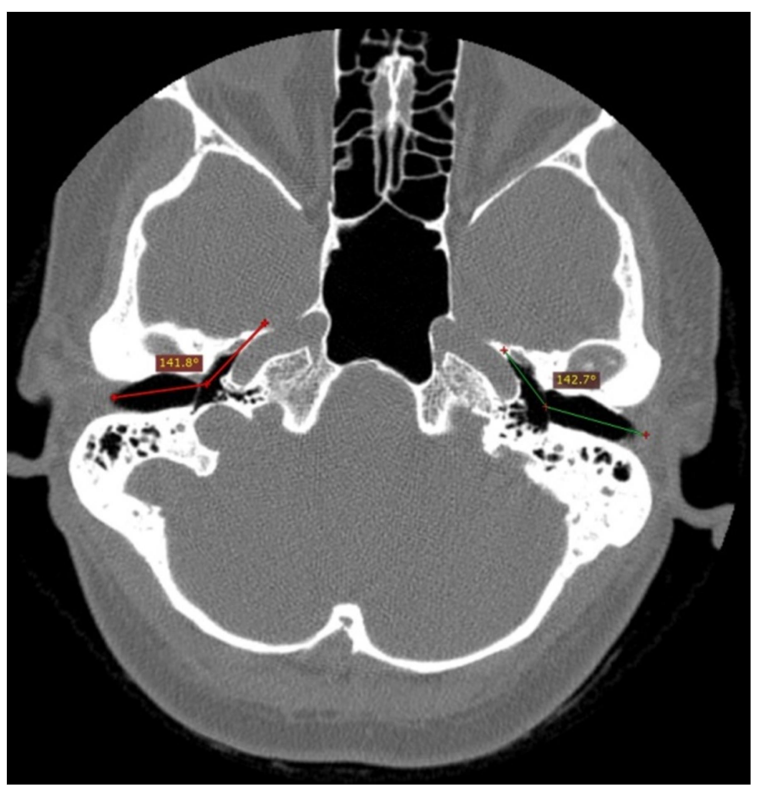

Figure 2. Measurement of bilateral tubotympanic angles on an axial view of temporal bone CT. The right side is a normal ear (red lines).

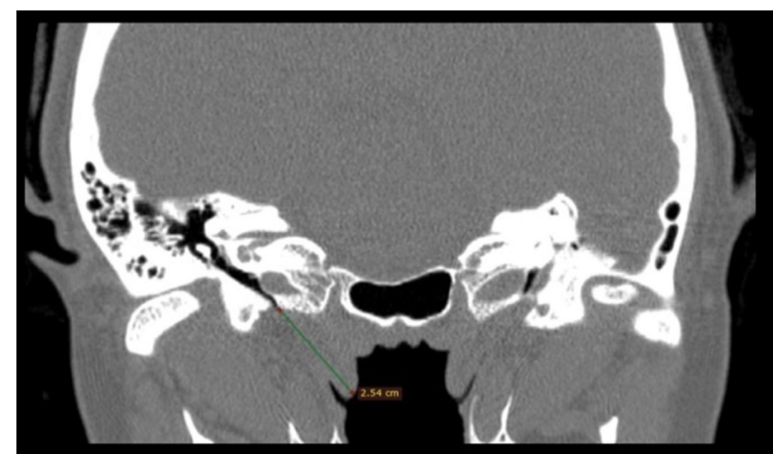

Figure 3. Length of cartilage portion of right Eustachian tube is measured on coronal reformat after multiplanar reconstruction of temporal bone CT

\section{RESULT}

Demographic data of the sample consisting of gender and age group are shown in Table 1. The 
sample of this study consisted mainly of men (53.4\%).

Most of the samples are in the age group of 21 to 40 years.

Table 1. General characteristics of the study participants

\begin{tabular}{lll}
\hline \multicolumn{1}{c}{ Characteristics } & $\mathbf{n}$ & $\%$ \\
\hline Gender & 31 & 53,4 \\
Male & 27 & 46,6 \\
Female & & \\
Age (years) & 10 & 17,2 \\
$11-20$ & 16 & 27,6 \\
$21-30$ & 14 & 24,1 \\
$31-40$ & 10 & 17,2 \\
$41-50$ & 4 & 6,9 \\
$51-60$ & 4 & 6,9 \\
$>60$ & & \\
Ear side & 35 & 60,3 \\
Right & 23 & 39,7 \\
Left & & \\
\hline
\end{tabular}

Table 2. Mean and $p$-Value of Eustachian Tube Measurement in All Groups

\begin{tabular}{lccc}
\hline & $\begin{array}{c}\text { Pretympanic } \\
\text { diameter }\end{array}$ & $\begin{array}{c}\text { Tubotympanic } \\
\text { angle }\end{array}$ & $\begin{array}{c}\text { Cartilage } \\
\text { length }\end{array}$ \\
\hline Gender & 4,62 & 143,5 & 2,67 \\
Male & 4,36 & 143,3 & 2,67 \\
Female & $(p=0,14)$ & $(p=0,89)$ & $(p=0.94)$ \\
& & & \\
Ear side & 4,59 & 143,4 & 2,66 \\
Right & 4,36 & 143,4 & 2,69 \\
Left & $(p=0,21)$ & $(p=0,97)$ & $(p=0,43)$ \\
\hline
\end{tabular}

Table 2 shows the mean and $p$-value of the three measurement parameters for each group. Comparisons between each group we studied using an independent sample T-test. The mean of pretympanic diameter was $4,62 \mathrm{~mm}$ in the male's group and 4,36 $\mathrm{mm}$ in the female's group. The mean of pretympanic diameter was $4,59 \mathrm{~mm}$ in the right side group and 4,36 $\mathrm{mm}$ in the left side group. Pretympanic diameter in men is greater than in women, with an insignificant difference. It was also greater in the right ears group than in the left ears group with an insignificant difference. The mean of tubotympanic angle was $143,5^{\circ}$ in the male's group and $143,3^{\circ}$ in the female's

group, with an insignificant difference. The mean of tubotympanic angles in the two groups of ears has no difference, which was $143.4^{\circ}$. The mean cartilage portion length was $2.67 \mathrm{~cm}$ in both men and women. The mean cartilage portion length of the Eustachian tube in the right side group was $2,66 \mathrm{~cm}$ and in the left side group was $2,69 \mathrm{~cm}$. The mean cartilage length is greater in the left side group than in the right side group with an insignificant difference. The $p$-value in all groups is more than 0.05 , which indicates that all differences in values in each group are not significant enough. The smallest $p$-value is owned by the pretympanic diameter in gender groups $(p=0,14)$. This shows that the difference in pretympanic diameter in gender groups has a value that can be considered.

\section{DISCUSSION}

Radiologic evaluation, especially CT is essential when preoperatively evaluating the middle ear and mastoid. The recently developed multiplanar reconstruction technique has made it possible to obtain images parallel or perpendicular to the long axis of the Eustachian tube. ${ }^{11,12}$ This study shows the results of the measurement of several dimensions of the Eustachian tube on temporal bone CT imaging. The osseous part of the Eustachian tube is always open at all times in people with a good middle ear condition, in contrast to the cartilaginous part, which will be closed at rest and open during swallowing or when the Valsalva maneuver is performed. The pretympanic segment of the Eustachian tube lies entirely within the petrous portion of the temporal bone and is directly related to the anterior wall of the superior part of the middle ear.

Our study shows that the mean value of pretympanic diameter in men is greater than the mean value of it in women, with a difference that is not so significant. In the measurement of tubotympanic angle, the difference is not that much difference between men and women. There is no difference in the measurement of the cartilage portion length between men and women. The insignificant differences in all Eustachian tube measurement parameters in the men 
group and women group show that the condition and anatomical position of the Eustachian tube are not affected by gender. A study conducted by Lih et al (2017) shows there is no difference between middle ear function in men and women. ${ }^{13}$ Our study supports the results obtained in that study because it is said that the size and condition of the Eustachian tube are believed to affect the function of the middle ear more than the gender predisposing factor. ${ }^{13,14,15}$

In this study, we obtained that the pretympanic diameter in the right ear is greater than in the left ear, although with a difference that was not significant. The greater the pretympanic diameter is assumed that the better the Eustachian tube function. ${ }^{5,16}$ A study conducted by Keefe et al showed that the hearing function of the right ear was more dominant than the left ear. ${ }^{17} \mathrm{~A}$ greater pretympanic diameter value in the right ear than the left ear obtained in our study supports the results of that study. Reduction of the size of pretympanic diameter can be one of the predisposing factors for the development of chronic suppurative otitis media. ${ }^{18}$ The tubotympanic angle and cartilage portion length do not have differences on both sides of the ear.

Experts believe that the human race and body size influence the size of the Eustachian tube. ${ }^{17,19}$ There are several imaging studies about the middle ear and Eustachian tube that have been conducted in Indonesia, but this study provides more detailed information on multidimensional measurement of Eustachian tube that represents Indonesian people. ${ }^{20}$ From studies that have been reported in Indonesia, there has never been a complete evaluation of Eustachian tubes in the form of pretympanic diameter, tubotympanic angle and length of cartilage portion. The results of this study, it is expected to provide the basic data on the anatomical state of the Eustachian tube, in the form of pretympanic diameter, tubotympanic angle and length of cartilage portion in Indonesian people.

\section{CONCLUSION}

The mean value of pretympanic diameter in men is greater than in woman. The mean value of pretympanic diameter in the right ear is greater than in the left ear. The mean value of the tubotympanic angle both in the right ear and left ear had no significant difference. Similarly, the mean of tubotympanic angles in men and women has almost the same value. There was no difference in cartilage length in men and women. This value was also almost the same in the right ear and left ear. The $p$-value in all groups is more than 0.05 , which indicates that all differences in values in each group are not significant enough. However, through this research, we can get a picture of the multidimensional measurement of the Eustachian tube in Indonesian people.

\section{ACKNOWLEDGEMENTS}

The researchers would like to thank all people who have helped them in the research process. This gratitude especially goes to patients, radiographers, and members of the Department of Radiology, Hasanuddin University, who have been very supportive during data collection.

\section{REFERENCES}

1. Bluestone $C D$. Eustachian tube: Structure, function and role in middle-ear disease. 2nd Edition. Connecticut: PMPH-USA; 2017.

2. Emanuel DC, Maroonroge S, Letowki T. Auditory function: Physiology and function of the hearing system. In: Rash, CE, Russo MB, editors. HelmetMounted Displays: Sensory, Perceptual, and Cognitive Issues, Edition: 1, Chapter: 9. Fort Rucker: USAARL; 2009. pp. 307-334.

3. Swarts JD, Bluestone CD, Luntz M, Doyle WJ. Eustachian tube, middle ear and mastoid anatomy, physiology, pathophysiology and pathogenesis. Journal of American Academy of Otolaryngology-Head and Neck Surgery. 2013; 148:E26-36.

4. Ghada MWF. Ear anatomy. Global Journal of Otolaryngology. 2017;4(1).

5. Jufas $\mathrm{N}$, Marhioni D, Tarabichi M, Patel $\mathrm{N}$. Endoscopic anatomy of the pretympanum. Otolaryngol Clin N Am. 2016; 49:1107-19.

6. Chauhan B, Chauhan K. A comparative study of eustachian tube functions in normal and diseased ears with tympanometry and videonasopharyngoscopy. Indian J Otolaryngol Head Neck Surgery. 2013; 65(3):468-76. 
7. Chen JY, Mafee MF. Computed tomography imaging technique and normal computed tomography anatomy of the temporal bone. Elsevier Inc. 2014; 25:3-12.

8. Aksoy S, Sayin I, Yazici ZM, Kayhan FT, Karahasanoglu A, Hocaoglu E, et al. The evaluation of the angles of eustachian tubes in the patients with chronic otitis media on the temporal computerized tomography. Niger J Clin Pract 2016;19:318-22.

9. De Brucker Y, Buisseret T, Allemeersch G, De Mey J. Basic and advanced temporal bone anatomy using different figures as landmarks. European Society of Radiology [online poster]. March 2017 (downloaded on 7 February 2019). Available at https://www.researchgate.net/publication/32835438 $\underline{5}$

10. Bluestone CD, Simons JP, Healy GB, editor. Pediatric Otolaryngology. USA: People's Medical Publishing House; 2014.

11. Abele TA, Wiggins $\mathrm{RH}$. Imaging of the temporal bone. Radiol Clin N Am 2015;53:15-36.

12. Falkenberg-Jensen BF, Hopp E, Jablonski GE, Pripp AH, Silvola JT. The cartilaginous eustachian tube: Reliable ct measurement and impact of the length. Am J Otolaryngol. 2018;39(1) 436-40.

13. Lih AC, Zakaria MN, Mohammad RA, Rashid MFN. Effects of ethnicity and gender on the middle ear function in Asian adults. Indian Journal of Otolology. 2017;23(9):4-7.
14. Petrusa MM, Cvetko E. Sectional Anatomy of Auditory Tube. Bosnian Journal Of Basic Medical Sciences. 2004; 4 (2): 10-16.

15. Smith ME, Scoffings DJ, Tysome JR. Imaging of the eustachian tube and its function: a systematic review. Neuroradiology. 2016;58(6):543-56.

16. Shim HJ, Choi AY, Yoon SW, Kwon KH, Yeo SG. The value of measuring eustachian tube aeration on temporal bone CT in patients with chronic otitis media. Clinical and Experimental Otorhinolaryngology. 2010; 3(2): 59-64.

17. Keefe DH, Gorga MP, Jesteadt W, Smith LM. Ear asymetries in middle ear, cochlear and brainstem responses in human infants. J Acoust Soc Am. 2008;123 (3):1504-12.

18. Rennie CE, Gutierrez M, Darby Y, Lund VJ. Investigation of the incidence of eustachian tube dysfunction in patients with sinonasal disease. Rhinology Online Journal. 2018;1(2) :85-9.

19. Janzen-Senn I, Schuon RA, Tavassol F, Lenarz T, Paasche G. Dimensions and position of the eustachian tube in humans. PloS One. 2020;15(5): 11-2.

20. Masita S. Perbandingan sudut tuba eustachius pada penderita otitis media supuratif kronis dan telinga normal berdasarkan CT scan temporal di RSUP Haji Adam Malik Medan (tesis). Medan: Medical Faculty, University of Sumatera Utara; 2017. 